University of Michigan Law School

University of Michigan Law School Scholarship Repository

\title{
Liability of Hospitals for the Negligence of Their Physicians and Nurses
}

\author{
Harry B. Hutchins \\ University of Michigan Law School
}

Available at: https://repository.law.umich.edu/articles/1315

Follow this and additional works at: https://repository.law.umich.edu/articles

Part of the Legal Remedies Commons, Medical Jurisprudence Commons, and the Torts Commons

\section{Recommended Citation}

Hutchins, Harry B. "Liability of Hospitals for the Negligence of Their Physicians and Nurses." Mich. L. Rev. 5 (1907): 552-9.

This Response or Comment is brought to you for free and open access by the Faculty Scholarship at University of Michigan Law School Scholarship Repository. It has been accepted for inclusion in Articles by an authorized administrator of University of Michigan Law School Scholarship Repository. For more information, please contact mlaw.repository@umich.edu. 
Liability of Hospitals for the Neghigence of Their Physicians and NuRSEs. - This question was recently examined by the Supreme Court of Utah in the case of Gitzhoffen v. Sisters of Holy Cross Hospital Association, 88 Pac. Rep. 69I (Jan. 26, I907), and the opinion filed may well serve as a basis for comment. The hospital association was sued for damages for injuries that plaintiff claimed to have sustained through the negligence of defendant's nurses. At the time that plaintiff was received as a patient, he was suffering, and had for some time suffered, with a serious affection of the eyes. He had received private treatment, but as he was without means, his case was called to the attention of the county authorities and an arrangement was made whereby, for a small consideration to be paid by the county, he was received by the defendant hospital, with the understanding that his physician, who was an assistant county physician, might continue to treat the case. This physician and an oculist whom he called to see the case, both explained in detail to the nurse in charge just what should be done and that blindness would undoubtedly result if the directions were not carefully followed. The evidence of the plaintiff tended to sustain the foregoing statements and to show also that the blindness of plaintiff which ensued, was due to the failure of the attending nurse to carry out the directions given to her by the physician. As a part of his case, the plaintiff also put in evidence the articles of incorporation of the defendant which showed, among other things, that the defendant had been duly incorporated with a stated capital stock divided into a stated number of shares; that while the objects of the corporation were to maintain and conduct hospitals for the treatment of the sick and the care of the infirm and schools for the education and training of nurses, it was in form essentially a corporation for business purposes. By these articles and by the law under which it was organized, this corporation, says the court, "is given all the rights, powers and privileges that are usually, or that can be, given to a business corporation." The court suggests that thereunder dividends could be declared and paid to stockholders as in the ordinary business corporation; that "the articles are in harmony with those of a business corporation and wholly inconsistent with those of a charitable organization," and that "the articles upon their face purport to create an organization for pecuniary profit."

The evidence of the defendant tended to show that at the time plaintiff was received at the hospital his disease was so far advanced that he was beyond the reach of medical aid and that his blindness was due to the nature of the disease from which he was suffering and not to the negligence of any of the servants of the defendant. Notwithstanding the objection of the plaintiff, the defendant was permitted to show that the hospital was a charitable institution and that all of its income and revenues were disbursed in its support and in the care of its inmates, and that it was not conducted for profit. Evidently upon the theory that the hospital was a charitable institution and therefore not liable for the negligence of its nurses, in the absence of all evidence of negligence in their selection, the trial court directed a verdict for the defendant. 
But the Supreme Court held it to be error to permit the defendant to show by parol the charitable character of the hospital, as its character under the law must be determined from its articles of incorporation. "It has been quite generally held," said the court, "that the nature of the corporation must be determined from its articles of association, and that its character cannot be changed or modified by parol evidence; that the object and purpose for which a corporation is organized must be gathered alone from the written instrument, and it cannot be aided or varied or contradicted by testimony or averments aliunde the instrument itself," citing authorities. To the claim of the defendant's counsel that even if the corporation was not charitable, it was yet entitled, under the law, to the protection accorded to charitable institutions, in regard to the negligence of properly selected employees, by virtue of the fact that the relation between the plaintiff and defendant was really a charitable one, he neither paying nor being obliged to pay anything to defendant for its care and services, the court suggested that "if the defendant had received the plaintiff as a mere object of charity, then it owed him no duty, except perhaps the exercise of care in the selecting of a physician or nurse, if it had undertaken to do so. If, on the other hand, it received him for treatment under a contract for pay, and undertook and assumed to treat him, then it owed a duty not only to exer-cise reasonable care in the selection of a nurse, if it had undertaken that duty, but also the duty to use reasonable care in the giving of the treatment and the doing of that which it had agreed and assumed to do." It was admitted by the defendant in its answer that it received the plaintiff for treatment under a contract for hire with the county. While the plaintiff was under no pecuniary obligation to the defendant for its treatment, the county had made itself so by contract. "If the defendant agreed with the county," said the court, "to receive and treat the plaintiff for pay, we cannot see on what principle it did not owe him the same duty in the premises as if it had directly made the agreement with the plaintiff to receive and treat him for pay." For the error suggested and also because in the opinion of the court there were questions of negligence in the case that should be submitted to a jury, the judgment of the lower court was reversed and a new trial ordered.

If a hospital is conducted as a business enterprise for profit, it is undoubtedly liable for the regligence of physicians and nurses employed and paid by the hospital. The doctrine of respondeat superior applies in such a case. See Broum v. La Société Francaise, I38 Cal. 475, 7I Pac. Rep. 516. It is apparent that the counsel for the defendant hospital tried to escape this doctrine and to bring his case within the proposition that has been generally recognized by the courts, and that is referred to in the opinion as sustained by the great weight of authority, that a hospital upon a charitable foundation and conducted as a charitable institution is not liable for the negligent acts of its physicians, nurses and other employees, if it has not been guilty of negligence in selecting them and does not retain them after it has knowledge of their incapacity. It may be suggested parenthetically that, as appears in sev- 
eral of the cases cited below, a hospital upon such a foundation and so conducted does not lose its character as a charity so that it will be liable for the negligent acts of its physicians, nurses and other employees because, when a patient is able to pay, it charges a small fee for room, board and care, such fee being for the purposes of the hospital. See McDonald v. Massachusetts General Hospital, 120 Mass. 432, 21 Am. Rep. 529; Benton v. Trustees of Boston City Hospital, I40 Mass. 13, 54 Am. Rep. 436; Fire Insurance Patrol v. Boyd, 120 Pa. St. 624; Hearns v. Waterbury Hospital, 66 Conn. 98, 33 Atl. 'Rep. 595, 3I L. R. A. 224; Downes v. Harper Hospital, IoI Mich. 555, 60 N. W. Rep. 42, 25 L. R. A. 602, 45 Am. St. Rep. 427; Williamson v. Louisville Industrial School, 95 Ky. 25I, 24 S. W. Rep. I065, 23 L. R. A. 200,44 Am. St. Rep. 243; Perry v. House of Refuge, 63 Md. 20, 52 Am. Rep. 495; Plant System Relief and Hospital Depot v. Dickerson, 118 Ga. 647, 45 S. E. Rep. 483; Papke v. Grace Hospital, I30 Mich. 493, 90 N. W. Rep. 278; Collins v. N. Y. Post Graduate Medical School, 59 App. Div. Rep. 63, 69 N. Y. S. 106.

While the foregoing proposition is sustained by abundant authority, the courts are not agreed as to the reason upon which it should be based. Some hold that the reason is to be found in the inviolable character of trust funds. The argument is that as the funds of a public charitable hospital are held in trust for a particular charitable purpose, it would be a breach of that trust to apply them, or any part of them, to any other purpose than the one provided, as would be the case if a judgment for damages for the negligence of a servant of the hospital were to be satisfied out of such funds. And as such a judgment cannot be satisfied out of the trust funds, it is of no force or effect and should not be permitted. Such in effect is the reasoning and conclusion of the Supreme Court of Michigan in Downes v. Harper Hospital, 10I Mich. 555, 60 N. W. Rep. 42, 25 L. R. A. 602, 45 Am. St. Rep. 427. This was an action for damages for injuries sustained by a patient by reason of the negligence of employees of the hospital. The attitude of the court is shown by the following quotation from the opinion: "If the contention of the learned counsel for the plaintiff be true, it follows that the charity or trust fund must be used to compensate injured parties for the negligence of the trustees, or architects and builders, upon whose judgment reliance is placed as to plans and strength of materials; of physicians. employed to treat patients; and of nurses and attendants. In this way the trust fund might be entirely destroyed and diverted from the purpose for which the donor gave it. Charitable bequests cannot be thus thwarted by negligence for which the donor is in no manner responsible. If, in the proper execution of the trust, a trustee or an employee commits an act of negligence, he may be held responsible for his negligent act; but the law jealously guards the charitable trust fund, and does not permit it to be frittered away by the negligent act of those employed in its execution. The trustees of this fund could not by their own direct act divert it from the purpose for which it was given, or for which the act of the legislature authorized the title to be vested in the defendant. It certainly follows that the fund cannot be indirectly diverted by the tortious or negligent acts of 
the managers of the fund, or their employees, though such acts result inx damage to an innocent beneficiary. Those voluntarily accepting the benefit of the charity accept it upon this condition." See, also, Perry v. House of Refuge, $6_{3}$ Md. 20, 52 Am. Rep. 495. The decision in this case is based largely upon Feoffees of Heriot's Hospital v. Ross, I2 Clark \& Finnelly, 507, in which LoRD COTTENHAM said: "To give damages out of a trust fund, would not be to apply it to those objects whom the author of the fund had in: view, but would be to divert it to a completely different purpose." Williamson v. Louisville Industrial School of Reform, $95 \mathrm{Ky}$. 25I, $24 \mathrm{~S}$. W. Rep: I065, 23 I. R. A. 200,44 Am. St. Rep. 243.

It has been suggested in criticism of the reasoning of the cases just cited that if a public charity cannot be held liable for the negligence of its" servants, if due care in appointing them has been exercised, because of theinviolability of its trust funds, then it must follow that the funds of a public charity cannot be diverted in payment of judgments for any torts committed. in the administration of the trust, while it is well settled that for some torts the funds of a public charity may be held liable. See Powers v. Massachusetts Homeopathic Hospital, 47 C. C. A. I22, 109 Fed. 294, 65 I. R. A. 372, in which the court after citing several authorities in support of the suggestion says: "If those in charge of a hospital unlawfully permit the escape of filth upon neighboring land, or close a right of way across the premises of the hospital, may not the corporation, in some cases at least, be sued in tort? We think the question answers itself." And in further discussion of thematter this court says: "If" this proposition is true, then $* * *$ it follows that if the defendant, by its servants, should negligently permit the staircase of a building from which it derives a profit to fall out of repair, it would not be liable for damages suffered by reason of this negligence. It follows, also, that a person walking along the street, and injured by the fall of a stone cornice negligently maintained above the sidewalk, can or cannot recover for the damage suffered, according as the building from which the stone falls, is the property of a private individual or of a public charity. Indeed the principle extends even further than this. There is no: less impropriety in diverting funds impressed with a trust for the benefit of individuals than in diverting those impressed with a trust for a publiocharity. Yet the effectual, though indirect, liability of a private trust fund for the torts of those concerned in its management is undoubtedly recognized. It is true that a suit cannot be maintained against a trustee, as such, for torts committed in the management of the trust property. The suit is brought against the trustee as an individual. The judgment and executionrun against him individually. When these are satisfied, however, the trustee is reimbursed from the trust estate, unless individually at fault," citing authorities. It is quite apparent that the reasoning that bases the immunity of charities from judgments for the negligence of servants upon the inviolability of the trust funds of such charities, is not above criticism. It proves too much.

Some courts find a reason for this immunity of public charities in the: 
doctrine of public policy. They hold that public policy will not justify an extension of the doctrine of respondeat superior to such charities. "We think," says the Supreme Court of Connecticut, "the law does not justify such an extension of the rule of respondeat superior. It is perhaps immaterial whether we say the public policy which supports the doctrine of respondeat superior does not justify such extension of the rule, or say that the public policy which encourages enterprises for charitable purposes requires an exemption from the operation of a rule based on legal fiction, and which, as applied to the owners of such enterprises, is clearly opposed to substantial justice. It is enough that a charitable corporation like the defendant, whatever may be the principle that controls its liability for corporate neglect in the performance of a corporate duty, is not liable, on grounds of public policy, for injuries caused by personal wrongful neglect in the performance of his duty by a servant whom he had selected with due care, but in such case the servant is alone responsible for his own wrong." Hearns v. Waterbury Hospital, 66 Conn. 98, 33 Atl. 595, 3I L. R. A. 224. In Union Pacific R. Co. v. Artist, 9 C. C. A. I4, ig U. S. App. 6i2, 60 Fed. 365,23 L. R. A. 58I, the court sustains the doctrine of the immunity of charitable hospitals from responsibility for the acts of their servants upon the theory that the funds of such hospitals are trust funds that cannot be diverted either directly or indirectly from the purposes for which they were given, and upon the further theory that the doctrine of respondeat superior does not apply as against such a charity, because by fair implication a charitable hospital, on account of the gratuitous character of the services rendered, "simply undertakes to exercise ordinary care in the selection of physicians and attendants who are reasonably competent and skillful, and does not agree to become personally responsible for their negligence or mistakes."

A reason for this immunity of public charities that appeals to the writer as fundamentally sound, is the one that really underlies the second of the theories just given, but which is more fully and clearly developed in the exhaustive opinion of JUDGE LOWELx, in the case of Powers v. Massachusetts Homcopathic Hospital, 47 C. C. A. I22, 109 Fed. 294,65 L. R. A. 372 . It is suggested in this opinion that if there is an agreement between a patient and the charitable hospital to hold the latter harmless for the acts of its servants, then it follows that the patient cannot bring an action against the hospital in case of injury through the negligence of such servants. And the court holds that an agreement of this kind arises "by necessary implication from the relation of the parties." "That a man," continues the court, "is sometimes deemed to assume a risk of negligence, so that he cannot sue for damages caused by the negligence, is familiar law. Such is the case of common employment, and such are the cases of athletic sports and the like. *** . Such is the case at bar. One who accepts the benefit either of a public or a private charity enters into a relation which exempts his benefactor from liability for the negligence of his servants in administering the charity; at any rate, if the benefactor has used due care in selecting those servants." 
Opposed to the doctrine of McDonald v. Massachusetts General Hospital, Powers v. Massachusetts Homcepathic Hospital and other cases hereinbefore cited, is the case of Glavin v. Rhode Island Hospital, I2 R. I. 4II, 34 Am. Rep. 675. This was an action brought against a public charitable hospital to recover damages for injuries sustained through the unskillful and negligent surgical treatment of the plaintiff by the surgical interne of the defendant. The court refused to recognize as sound the doctrine that a charity, like a hospital, should not, on the grounds usually alleged, be responsible for the negligence of its surgeons, nurses; servants, etc, and held the contrary to be the law. In regard to the argument that public policy justifies the immunity, this court says: "In our opinion the argument will not bear examination. The public is doubtless interested in the maintenance of a great public charity, such as the Rhode Island Hospital is; but it also. has an interest in obliging every person and every corporation which undertakes the performance of a duty to perform it carefully, and to that extent therefore it has an interest against exempting any such person and any such corporation from liability for its negligences. The court cannot undertake to say that the former interest is so supreme that the latter must be sacrificed to it." And concerning the argument based upon the inviolability of trust funds, the court after reviewing McDonald v. Massachusetts General Hospital and several of the English cases, says: The question here is whether a charitable corporation, like the Rhode Island Hospital which holds its property for the charity, is to be "relieved from all responsibility for the torts or negligences of its officers, trustees, agents, or servants. We have come to the conclusion, after much consideration, that it is not. We understand the doctrine of the cases which we have just been considering to be this: that where there is duty, there there is, prima facie at least, liability for its neglect; and that when a corporation or quasi corporation is created for certain purposes which cannot be executed without the exercise of care and skill, it becomes the duty of the corporation or quasi corporation to exercise such care and skill; and that the fact that it acts gratuitously, and has no property of its own in which it is beneficially interested, will not exempt it from liability for any neglect of duty, if it has funds, or the capacity of acquiring funds, for the purposes of its creation, which can be applied to the satisfaction of any judgment for damages recovered against it. We also understand that the doctrine is that the corporate funds can be applied, notwithstanding the trusts for which they are held, because the liability is incurred in carrying out the trusts and is incident to them." This case stands practically alone, and its authoritative force even in Rhode Island has been affected by subsequent legislation, for it is now provided by statute in that state that "no hospital incorporated by the general assembly of this state, sustained in whole or in part by charitable contributions or endowments, shall be liable for the neglect, carelessness, want of skill or for the malicious acts, of any of its officers, agents or employees in the management of, or for the care or treatment of, any of the patients or inmates of such hospital." See General Laws of Rhode Island (1896), pp. 538, 539. 
Some cases against hospitals have been decided by the application of the doctrine that is frequently used as a weapon of defence by municipal officers or bodies against whom a suit has been brought for the negligence of their servants, namely, that, under the law, the managers were exercising governmental powers, and that they, therefore, would be entitled to the exemption of the government from the doctrine of respondeat superior. The case of Richmond v. Long, if Gratt. 375, is of this kind. It was an action for the value of a slave lost by negligence of the servants of a city hospital. This hospital had been established under a city ordinance and was run as a city institution. The court in holding the city not liable applied the doctrine to which reference has been made. Other cases similar to this are the following: Maia v. Eastern State Hospital, 97 Va. 507, 34 S. E. Rep. 6I7, 47 L. R. A. .577; Sherbournè v. Yuba County, 2I Cal. 'II3, 8I Am. Dec. I5I; Murtaugh v. St. Louis, 44 Mo. 479 . These and similar cases, while usually cited as ibearing upon the question of the liability of a hospital upon a charitable foundation for the negligence of its servants, are not really in point. The hospital may be a public charity, but unless it is established and run by governmental authority, it is in no sense an agency of the government.

Other cases that fall naturally and immediately under the head of this discussion, are those that are brought against railway companies by parties receiving treatment in railway hospitals that have been established by the companies for the benefit of their sick or injured employees. These hospitals are usually established by the companies not for profit, but largely as charitable provisions for employees. And they have usually been held to be charitable in character, even though employees under their contracts with the roads contribute each month small sums toward their support, the remaining amount necessary being provided by the companies. As such hospitals are not run for profit but are on a foundation that is essentially charitable, the companies maintaining them are held not to be liable for the negligent acts of physicians, nurses and attendants, provided there has been the exercise of proper care in their selection. Sometimes this conclusion is based upon the proposition that the physician or nurse who has been guilty of negligence was not the servant of the employing corporation inasmuch as he or she acted independently of any orders from the corporation. The physician in treating the patient must be guided altogether by his own judgment, and the nurse takes orders from the physician in charge and not from any officer of the corporation. But the conclusion of some of the cases is based upon the doctrine that one who voluntarily receives medical aid gratuitously rendered, cannot maintain an action against the giver in the absence of any negligence in the selection of physicians, nurses, attendants, etc., etc. See Union P. R. Co. v. Artist, Ig U. S. App. 612, 60 Fed. 365, 9 C. C. A. 14,23 L. R. A. $58 \mathrm{r}$; Eighmy v. U. S. R. Co., 93 Iowa, 538,61 N. W. Rep. 1056, 27 L. R. A. 296; Plant System Relief and Hospital Depot v. Dickerson, II8 Ga. $647,45 \mathrm{~S}$. E. Rep. 483 . The question of the liability of railroad companies for the negligence of surgeons in the employment of the companies arises more frequently probably where the treatment of injured employees has 
not been in railroad hospitals, but in other places to which such employees have been taken. The principles applied, however, under such circumstances, are not different. See Chicago, B. \& $Q$. R. Co. v. Howard, 45 Neb. 570, 63 N. W. Rep. 872; Quinn v. Kansas City M. \& B. R. Co., 94 Tenn. 7r3, 30 S. W. Rep. I036, 28 L. R. A. 552, 45 Am. St. Rep. 767; South Florida R. Co. v. Price, 32 Fla. 46 , 13 So. 638 ; Poling v. S. A. \& A. P. Ry. Co. 32 Tex. Civ. App. 487,75 S. W. Rep. 69.

An examination of the cases herein cited will disclose that, although the hospital upon a charitable foundation is not liable for the negligence of its physicians and nurses, if due care has been exercised in their selection, a personal liability rests upon the party who has been guilty of the negligent acts. It is, therefore, no defense to an action for malpractice brought against a physician, that he acted as the servant of the hospital.

H. B. H. 